\title{
Research on Patent Law Education of Science and Engineering College Based on Scientific and Technological Innovation
}

\author{
Hongzhen Lin \\ School of Hengda Management, Wuhan University of Science and Technology Wuhan, China \\ 947 He Ping Street, Hubei Wuhan 430081, China
}

\begin{abstract}
This paper aims to study the measures to improve the quality of Patent Law education of Science and Engineering College and enhance college students' awareness of Patent Law. The research methods of this paper are mainly literature research and investigation. The research content of this thesis is the necessity for university students to learn patents, the analysis of problems in patent law education and measures to strengthen the education of patent law. The conclusion is that to improve patent law teaching quality, it is necessary to set up different types of courses, diversify teaching methods and improve the quality of teaching staff. In order to promote the practical application of student patent law, colleges and universities should gradually strengthen communication and cooperation with relevant social institutions, building intellectual property practice platform, cooperating with organizations such as social intellectual property guiding and training institutions and related intellectual property rights organizations.
\end{abstract}

Keywords - technological innovation; patent law education; college sudents; teaching methods

\section{INTRODUCTION}

Scientific and technological innovation is an important strategic support to improve social productivity and comprehensive national strength. The foundation and source of scientific and technological innovation is the cultivation of innovative and entrepreneurial talents. Innovative spirit and ability are the core connotations of innovative talents. This connotation includes not only strong innovative consciousness and ability, but also the protection, operation and management of innovative achievements according to existing laws. Nowadays, more and more college students are participating in the trend of "mass entrepreneurship, mass innovation". Colleges and universities have become an important part of the national science and technology innovation system. To a great extent, college students 'scientific and technological innovation ability affects and even determines the strength and level of China's future science and technology innovation. Scientific and technological innovation is inseparable from it. The education of patent law are very necessary for the students of science and engineering, in order to promote the level of cultivation of innovative talents in Colleges and universities, and better support the implementation of national innovation-driven development strategy and strong intellectual property rights [1]. Patent law is part of intellectual property rights. In the era of knowledge economy, scientific and technological progress plays a more and more important role in promoting the economy. All countries continue to strengthen the protection of intellectual property rights. In order to adapt to this new situation, cultivate talents who understand intellectual property law has become an important task of colleges and universities [2].

\section{ThE NeCESSity OF STRENGTHENING PATENT LAW EDUCATION FOR COLLEGE STUDENTS OF SCIENCE AND ENGINEERING COLLEGE}

\section{A. College Students' Needs for Innovation and Entrepreneurship}

China's current intellectual property education in Colleges and universities has made some achievements, but there are serious problems in patent law education for students of science and engineering, which can not meet the needs of society for technological talents with innovative consciousness and the growth of students of science and engineering. Some college entrepreneurs have experienced patent infringement or unintentionally infringed the patent rights of others [3]. Some college students have not received relevant education in school, resulting in the passive protection and application of patents in the process of innovation and entrepreneurship. Because of lack of patent law education in Colleges and universities, the enthusiasm of scientific and technological innovation of college students is affected. College students need to have a full understanding of intellectual property issues in the process of entrepreneurship in order to protect their legitimate interests [4].

\section{B. Needs for Building an Innovative Country}

Science and technology are the foundation of national prosperity, and innovation is the soul of national progress. In modern China, the development of science and technology is accelerating China's development [5].Scientific and technological innovation is inseparable from the protection of intellectual property rights. In the era of knowledge economy, the production, diffusion, application and transformation of knowledge almost contain all the secrets of sustainable economic and social development. Intellectual property 
education is an important part of China's intellectual property strategy. [6] Young College students, as the most dynamic group in society, have strong innovation pursuit and creativity. Institutions of higher learning should attach importance to intellectual property risk education for students in order to adapt to the development of the times and meet the challenges of knowledge economy. In order to meet the needs of the times, it is necessary to strengthen the cultivation of College Students' various abilities. Colleges and universities in China should comprehensively upgrade the level of higher education with innovation ability as its soul, and carry out risk awareness education of intellectual property rights for college students around the pursuit and protection of innovation [7]. To cultivate the scientific and technological innovation quality of contemporary college students and strengthen the prevention education of knowledge property risk has become the need of building an innovative country in China. Opening patent law courses in Universities of science and engineering is an important safeguard for cultivating innovative, practical and compound talents [8].

As an important force in the future development of science and technology and economy, university students of science and engineering are the main force in scientific and technological innovation. The education of patent law for university students of science and engineering will help stimulate their technological innovation and improve their technological innovation ability, thus helping our country to occupy a favorable position in International competition [9]

\section{PROBLEMS ANALYSIS OF PATENT LAW EDUCATION FOR COLLEGE STUDENTS}

\section{A. Lack of Attention to Patent Law Education}

There are outstanding problems in the orientation of undergraduate education objectives, curriculum and the supply of teachers for intellectual property specialty. This also affects the education of patent law. For a long time, our intellectual property education mainly focuses on law education, and relatively neglects the intellectual property education of university students of science and technology, let alone patent law education. The focus of the teaching object is law students, ignoring the cultivation and education of intellectual property rights for non-law majors [10]. In terms of curriculum structure, it does not fully reflect the characteristics of patent law as a practical discipline integrating professional technology, law, economics and management. In terms of teaching content, most of them focus on jurisprudence and lack of practical skills education. As a result, quite a number of university students of science and technology do not know the object and scope of patent law protection and how to obtain patent law protection, and they do not know how to apply for patents and use patent documents for scientific research [11]. Patent law education is not carried out according to the characteristics of different disciplines and specialties.

\section{B. Lack of Adequate Teaching Resource.}

Firstly, the teaching staff of patent law is small. The overall teaching staff of patent law is weak and fluidity is high, and there is a lack of mature and stable professional teaching team. Second, the structure of patent law teachers needs to be further optimized. Existing teachers lay particular stress on theoretical research, lack practical training, and lack the practical ability to deal with intellectual property affairs skillfully [12]. At the same time, the disciplinary background of teachers is often limited to law, and there is a lack of compound talents who know not only law but also management economics and technology science.

\section{Backward Teaching Methods.}

Patent law is a highly integrated subject, so we should adopt a knowledge dissemination method combining classroom teaching with practical teaching. However, at present, most of the students still rely on the study of the course "Legal Basis" to understand the knowledge of patent law. Even if there are relevant elective courses, they still stay at the stage of traditional classroom teaching and legal education. Moreover, the content of the course teaching is not systematic and lags behind the development of science and technology and the times. Educational methods are not well utilized, related data information systems, literature construction and network teaching platform are missing, and the practical teaching link is almost blank.

\section{MEASURES TO STRENGTHEN THE EDUCATION OF PATENT LAW}

\section{A. Setting up different types of courses reasonably and paying attention to the integration of patent law education and related professional courses.}

The characteristics of intellectual property determine that intellectual property curriculum should be added according to the characteristics of each specialty. Through subject teaching, intellectual property education ideas should be infiltrated, teaching contents and key points should be rationally arranged, linkages between courses should be emphasized, and topnotch innovative talents should be mastered accordingly through a well-structured curriculum system. Intellectual Property Knowledge and Skills. Universal education of patent law can be carried out in Universities of science and engineering according to the situation. Through the popularization of patent law education, help students to build up awareness of intellectual property rights, on the one hand, stimulate students' innovative potential, on the other hand, in the process of innovation, can effectively use and protect the new knowledge, new methods and new technologies generated The curriculum content of intellectual property should embody three combinations: one is the combination of patent law, science and technology, and management. In particular, the imparting of knowledge on patent application, protection, operation and patent agency services should be strengthened. Second, the combination of patent law and professional learning. 


\section{B. Diversifying teaching methods to improve students 'comprehensive quality}

The teaching of "Patent Law" combines law with science and engineering and focuses on law. The transfer from traditional theory teaching to the teaching mode combining theory with practice is a good starting point for the teaching reform of patent law. In the process of combining theory with practice, neither of them can be weakened or neglected. Aiming at the orientation of "having both ability and moral integrity" and improving students "comprehensive quality in an all-round way, under the guidance of the trinity of "cultivating people with moral integrity, ability orientation, innovation and entrepreneurship", aiming at the overall development of students, taking the growth of students as the orientation, deepening innovation and entrepreneurship education and expanding social practice teaching. Education should form a mode of education that combines value shaping, innovative practice, skill development, quality cultivation and knowledge imparting, so as to improve students' comprehensive quality in an all-round way.

The combination of classroom teaching and practical teaching. Simulated teaching method is a teaching method introduced from engineering. In the course of patent law teaching, this method can better accomplish the teaching objectives and make up for the shortcomings of traditional teaching methods. It also has a positive effect in relevant courses such as patent retrieval and patent agency practice, which is beneficial for students to better grasp the knowledge of legal theory. Knowledge is applied to practice and adapts to social competition more quickly [13]. The main points are as follows: practical courses should be put in an important position, necessary credits should be set up, and students' practical ability to use knowledge should be emphasized. Students can be encouraged to practice or start their own businesses through organizing social surveys and industry research, and patent literature retrieval, patent application, patent transaction, patent disputes and patent rights. Shortterm special training for students in litigation, strengthening cooperation with relevant law firms, corporate legal departments and other units, etc., to enable students to grasp the practical operation of related patents through practice, etc.

Classroom teaching, various competitions, scientific research practice, extracurricular activities and network resources are the three platforms for training innovative and entrepreneurial talents. Patent law education should also rely on these three platforms. Therefore, the idea design of patent law education in Colleges and universities should emphasize the role of three platforms infiltration at different levels. As the first classroom, classroom teaching should provide rich intellectual property rights and academic soil for innovative talents, focusing on the scientific design of training objectives, curriculum, teaching methods and other links, forming a scientific and reasonable teaching system, so that students can grasp a solid theoretical basis[14]. As the second classroom, scientific research practice and extracurricular activities are the extension of traditional teaching. We should form a practical system of intellectual property education by carrying out subject research, practical teaching, social investigation and abundant extracurricular activities, so as to provide a practical platform for training top innovative talents to transform theoretical knowledge into practical application ability.

\section{Improving the quality of teaching staff, coordinating and Integrating the strength inside and outside the School.The development of education can not be separated from the support of talents}

If universities want to carry out the teaching activities of intellectual property rights, the scientific construction and reasonable training of teachers are indispensable. On the basis of the existing situation, the teaching staff engaged in patent law teaching and research should be reconstructed. Firstly, we should vigorously introduce a number of high-quality teaching talents with interdisciplinary knowledge background and optimize the subject structure of patent law teachers. Second, we should vigorously strengthen the training of existing teachers. To select excellent teachers to visit and study abroad, to understand the latest technology and knowledge abroad, to master scientific teaching methods and experience, to improve the professional quality of teachers, and to promote China's patent law education to be in line with international standards as soon as possible. In addition, teachers can be selected to study for degrees in universities with strong development of intellectual property specialty in China, so as to improve their teaching level, academic stamina and scientific research ability. Thirdly, to build a strong part-time teaching team, we should fully mobilize the positive resources of all sectors of society, and absorb intellectual property professionals with theoretical level and practical experience, such as judges, lawyers, management cadres and agents of patent institutions, into the teaching team, inviting them to teach regularly in schools or to set up lectures, etc. In order to form an organic combination of intellectual property teaching theory and practice in the composition of teachers. In addition, colleges and universities can also integrate and share teachers and carry out collaborative intellectual property education [15]. Professionals should carry out teaching, training and practice activities to ensure the effective integration of intellectual property theory education and practical guidance.

\section{CONCLUSION}

As the main group of knowledge innovation in the future, university students of science and technology are the main force and pillar of science and technology in the future. Patent law is the basis of independent innovation and an important means of participating in market competition. If scientists and technicians lack sufficient knowledge of patent law, their intellectual achievements will be difficult to transform from technological advantages to market advantages. It is important to strengthen the education of patent law in Universities of science and engineering. The smooth development of patent law education in Universities of science and engineering is inseparable from the rational curriculum setting, the improvement of teaching methods, the improvement of teachers and the creation of a good educational atmosphere. The specific goal of patent law education for university students of science and technology is to enhance their awareness of intellectual property rights, guide them to use the 
patent law system, improve their ability and level of creating, managing, applying and protecting intellectual property rights, guard against patent risks, try their best to avoid infringing on others 'patent rights, and create incentives for scientific and technological innovation and protection. The environment of patent right.

\section{ACKNOWLEDGEMENT}

This study was funded by the National social science fund education general project "entrepreneurial law education research based on risk control in science and Engineering University" No. BIA170192

\section{REFERENCES}

[1] Tang Xiang, Li Hang, Chen Shujuan. Necessity and mode of patent law education in Universities of science and engineering [J]. Henan Science and Technology, 2016 (16): 47-49.

[2] Wang Mengfei, Zhong Juan, Zhang Xunshu. Reform of SchoolEnterprise Cooperation and Integration Teaching Model for Intellectual Property Protection [J]. University (Research Edition), 2018, 367 (10): 34-40.

[3] Ma Yuanfeng. On the Significance and Feasibility of Strengthening Patent Law Education in Colleges of Science and Engineering [J]. Economic Research Guide, 2010 (19): 251-252.

[4] Li Xuanhong, Wang Luyu. Research on the Intellectual Property Education Architecture of Colleges and Universities from the Perspective of Double Creative Talents Training [J]. Journal of Jiamusi Vocational College, 2017 (8): 242-242

[5] May 4th. Brief discussion on the importance and ways of scientific and technological innovation in Colleges and universities [J].Journal of Kaifeng University, 2004, 18(1): 64-66.

[6] Qiu Honghua. Research on the Influencing Factors of China's Intellectual Property Education Based on AHP --- Also on the Path of Intellectual Property Talents Training [J]. Journal of Higher Education Research, 2018, 41 (2): 86-92

[7] Liu Ying, Zhou Yuzhi. On the Necessity of Intellectual Property Education for College Students [J]. Modern Information, 2001 (1): 5353 .

[8] Wang Quan, Yang Yang, Zeng Xiaojun. Exploration and Practice of Patent Law Elective Course Teaching Reform in Universities of Science and Engineering [J]. China Electric Power Education, 2012 (19) : 78-79.

[9] Jinbo, Zheng Shuxia. Some thoughts on strengthening intellectual property education for university students of science and technology $[\mathrm{J}]$. Legal system and economy, 2011 (3): 108.

[10] Deng Jianzhi. Research on Undergraduate Education of Intellectual Property Specialty [J]. Intellectual Property, 2017 (11): 79-85.

[11] Li Wei, Sun Xiaohong. Some Thoughts on Strengthening Intellectual Property Education for College Students of Science and Technology [J]. Educational Exploration, 2008 (1). 11-12

[12] Wang Jing. On the Model Transfer of Patent Law Course Teaching: Focusing on the Combination of Theory and Practice Teaching [J]. Education and Teaching Research, 2012, 26 (8): 83-85.

[13] Xie Haisheng. On the application of simulation teaching method in the teaching of patent law course [J]. Educational Observation (first half), 2017 (3): $117-118$

[14] Wang Guiping, Xu Xiangping. Research on Intellectual Property Rights Education and Practice for Undergraduates majoring in Engineering [J] New Campus, 2017 (4): 17-18.

[15] Liu Ying, Yin Zhiguo. Research on Intellectual Property Education Implanted into Top Innovative Talents Training [J]. China Adult Education, 2017 (1): 86-89. 